International Journal of Life Sciences
Available online at http://sciencescholar.us/journal/index.php/ijls
Vol. 2 No. 1, April 2018, pages: 1211
e-ISSN: 2550-6986, p-ISSN: 2550-6994
http://dx.doi.org/10.29332/ijls.v2n1.73

\title{
Build Recommendations Nitrogen Fertilization with the Development of the Period of Durian Crop Replanting
}

\author{
Made Suarta $^{a}$, I Nengah Suaria ${ }^{b}$, Ni Putu Anom Sulistiawati ${ }^{c}$ \\ Article history: Received 8 August 2017, Accepted in revised form 10 January 2018, Approved 1 February 2018, \\ Available online 5 February 2018
}

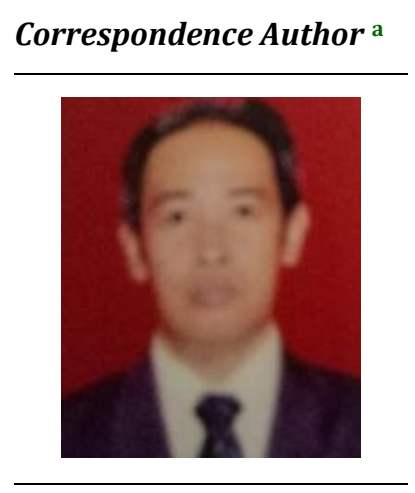

Keywords

Correlation;

Durian;

Fruit crops;

Leaf analysis;

Nitrogen fertilizer;

\begin{abstract}
The growing period of fruit crops requires nutrients for growth and development; this is very important in the physiology of fruit crops. Durian plants in determining the fruit harvest are largely determined by the process of growth development in plants. Leaf budding age is the main factor determining nutrient nutrients status in durian plants (Durio zibethinus Murr.). Durian plants require sufficient nutrients to obtain growth and fruit harvest; leaf analysis can be used as a guide in diagnosing nutrient status and fertilizer recommendations on durian plants. However, standard leaf sampling techniques should be accurately determined. The purpose of this research is to study and to know the proper dosage of fertilizer for durian plants associated with vegetative growth phase of leaf buds after fruit harvest the study was conducted in three locations: Sudaji Village, Munduk Bestala Village, and Sinabun Village, Buleleng Regency, March-November 2016. The leaves in the proper period of use are used as guidelines for fertilization when leaves have the best correlation relationship with period development vegetative plants. Leaf samples are taken periodically after the fruit harvest durian plants. Starting the early shoot period until the dormant buds period, the results showed that the nutrient concentration of nitrogen in leaves decreased with the age of leaf buds, the concentration on the initial leaf buds was higher than the full leaf buds. The correlation of nitrogen concentration from the development of leaf buds of durian plants has different nutrient requirements between leaf buds development, i.e. early leaf buds, adult leaf buds and dormant leaf buds; the smallest value is obtained on the growth of dormant buds. With a correlation coefficient of 0.82 each. At the time the leaves are young, the leaves do a great activity and require a supply of nutrients, as well as organic and water in the process of physiology of growth and development of plants in relation, can produce optimum fruit harvest.
\end{abstract}

a Agriculture Faculty Warmadewa University, Indonesia

b Agriculture Faculty Warmadewa University, Indonesia

c Agriculture Faculty Warmadewa University, Indonesia 
e-ISSN : 2550-6986, p-ISSN : 2550-6994@ Copyright 2018. The Author. SS Journals Published by Universidad Técnica de Manabí.

This is an open-access article under the CC BY-SA 4.0 license

(https://creativecommons.org/licenses/by-sa/4.0/)

All rights reserved.

\section{Contents}

Abstract

1. Introduction

2. Research Method

3. Results and Analysis

4. Conclusion

Acknowledgements

References

Biography of Authors

\section{Introduction}

Specifically, N, P, and K fertilizers are one of the most vital production facilities in supporting the increase of fruit production especially citrus fruits. The plant is highly responsive to the macro element, but its efficiency and effectiveness depend on local location. Given the durian fruit that produces a seasonal (biennial bearing) where the season is fruitful plants require optimal nutrition for the needs produce. Durian (Durio zibethinus Murr.) is a fruit that has a distinctive flavor and aroma that is popular with almost everyone. The sweet and fragrant fruits with the color of the flesh are not only white, yellow, orange and rich in calories, vitamins, fats, and proteins, but also the stem can be used as building materials (Purnomosidhi, 2007). The fulfillment of durian requirement is still difficult; this is due to lack of knowledge about the optimal mineral nutrition for the growth and production of fruit crops adequacy its need to increase the quantity, quality, and health of plants (Poerwanto, 2002) and uneven harvest (seasonal). September to October is the development of vegetative phase of durian plants (Stuckens et al., 2011). Among the important nutrients needed by fruit plants in the development and growth process include macro fertilizers such as; nitrogen $\mathrm{N}$ ), phosphor $(\mathrm{P})$, potassium $(\mathrm{K})$, calcium $(\mathrm{Ca})$, magnesium $(\mathrm{Mg})$, and sulfur (Mg). Each has different roles according to the type of fertilizer, such as nitrogen has a role in stimulating the growth of the plant as a whole. Serves in synthesizing chlorophyll, amino acids, and proteins in plants. Phosphates play a role in transporting metabolic results in plants such as flowering, fertilizing and stimulate seed formation and stimulating division and enlarging cells in plants. Magnesium elements play a role in enzyme transformation, also a core component in chlorophyll formation. Potassium plays a role in the process of photosynthesis, transport of assimilation, enzymes and including mineral water (Poerwanto, 2002). Fertilization efficiency in durian crops not only plays an important role in increasing farmer's income, but also related to the sustainable production system (Sustainable production), environmental sustainability, and saving of limited national energy resources. Locationspecific on orange plant area can be interpreted as a terrain that has a conductivity and land management as well as the application of technology that is similar and in one system. Based on that it is estimated that technological inputs, especially fertilizers, are also similar. One of the most effective tools can be used as an early reference in estimating optimal fertilizer requirement is a nutrient status map for $\mathrm{N}$, $\mathrm{P}$, and $\mathrm{K}$ fertilizers and where the land is overgrown by plants (Setiawan et al., 2006). Recommendations for appropriate nutrient delivery are expected to increase optimal production growth. Although the cost of nutrient analysis is high enough, it can be covered by increased yield and fruit quality and avoid waste of excess fertilizer. Furthermore, the addition of fertilizer is only given according to the needs of the plant, beyond the ability of the soil to provide. This is related to research conducted by Reddy (2014) on mango plants, to perform fertilization needs to be done a nutrient analysis. Nutrient analysis is a means of fertilizer management so that in the application of fertilizer on plants can be precise and efficient. From the management of fertilization through leaf analysis there are two ways that can be done are: soil analysis and analysis finger leaf plant. Soil analysis and leaf tissue analysis are tools that can be used to diagnose soil fertility status and recommend fertilization (Poerwanto, 2002). Indonesian durian production during 5 
years fluctuated, from 1992 to 1996 respectively are 152,501 kg, 170,857 kg, 268,562kg, 289,648kg, and 267.106kg. Besides domestic production, Indonesia also imports durian from Thailand which in 1997 the amount of durian import reached $756.856 \mathrm{~kg}$ with the value of 1086,185 US dollars, while its exports reached $695,614 \mathrm{~kg}$ with the value of 642,882 US dollars. Thus durian imports reached $69 \%$ greater than its exports (BPS, 2010). Durian fruit is one kind of tropical fruit that is very popular in our society. Indonesia is one of the countries with great opportunity to become producer and exporter of durian. Durian fruit is also a tropical specific plant that has high economic value for farmers' income, foreign exchange, and agribusiness needs. Although durian prospect is very good in the market, durian cultivation is still not paid attention in Leiwakabessy (2004). Durian cultivation has not been adequately considered this can be caused because of problems that arise. In Indonesia, durian garden management professionally and commercially is one of the new. Many obstacles need to be solved. Among the fulfillment of proper nutrition, suitable location, and cultivars that can live in the place. The low production of durian in Indonesia is caused by the existence of fertilization activities conducted by farmers. It is not efficiently and precisely, meaning that at the time of growth need to know how the optimum dose required, the nature or type of fertilizer, the location where the plant grows and when to apply it required by plants adapted to the development of the physiological period in the durian plant, soil type, and microclimate. This is one of the phenomena that is often ignored in the field by farmers. Based on the problems faced by farmers. In general, durian plants that have been producing now are old plants that are: more than fifteen years, and the plants are rarely fertilized, sometimes fertilized only using chicken manure. Although from some very limited research results are known until now the recommendation for citrus fertilization is not yet available completely.

Based on the problems mentioned above, the purpose of this research are:

1. Obtained information of change of nitrogen content $(\mathrm{N})$ in period of durian crop replanting

2. Provide a relationship of nitrogen $(\mathrm{N})$ leaf concentration with nitrogen $(\mathrm{N})$ content in the soil.

3. Finding the relationship between the results of leaf tissue analysis with soil nitrogen content on the development of the period of replanting on the durian crop.

Based on data from the Central Bureau of Statistics (2010-2015) the production of durian fruit Province I and almost in Indonesia or National experience fluctuation. In Jambi Province from 2010-2012 durian production increased where production of 327,681 quintals after it decreased in 2013 to 121,465 quintal and 2014 decreased to 55.8555 quintals and in 2015 increased again to 161,409 quintals at the national level from 2010-2014 durian production in 2010 has the lowest production of 492,139 tons. In 2011 it increased drastically to 883,969 quintals and then rose again in 2012 by 888,130 tons, and in 2013 it dropped to 759,058 quintals then in 2014 rose to 859,127 quintals. In Indonesia, durian crops are largely not mass cultivated, only as plants in yards and gardens on a small scale and seeds derived from seeds, causing production with high variability and low productivity, thus not being able to meet consumer demand both domestically and abroad Sukma and Harisudin, (2012). Though, Indonesia has the excellent natural potential for the development of durian plants, where climate and soil conditions that support the growth of durian plants. Through this research can be obtained meaning interstation, namely whether the nutrient content of $\mathrm{N}, \mathrm{P}$ and $\mathrm{K}$ in the leaf is very low status, low, medium, high, very high. So that only the plants with low nutrient content that need to be given the application of fertilization. So with known the state the benefits of this study used as a guide tool in preparing recommendations for fertilizer needs for citrus crops. The availability of fertilizer recommendations based on the results of the analysis on leaf tissue and by the needs of citrus crops for the continuity, quality, and health of plants, also facilitate for farmers in the proper and effective fertilization.

\section{Research Method}

Place and tie the research was conducted in Buleleng Regency in three locations, namely in Sudaji, Munduk Bastala, Sinabun area starting from January December 2016.

\section{Materials and Tools}

Durian plants studied are ten years old, as many as 20 crops from farmland area of three farmer groups each location Durian plants have been maintained in accordance with the way of farmer cultivation, which

Suarta, M., Suaria, I., \& Sulistiawati, N. (2018). Build Recommendations Nitrogen Fertilization with the Development of the Period of Durian Crop Replanting. International Journal Of Life Sciences (IJLS), 
is in accordance with the actual conditions in the field. Farmer cultivation mode is cultivated with organic fertilizer and irrigation only from rainfall. Routine maintenance is only in the form of, eradication of fungal disease on the citrus bark of citrus plant by using Alika disease. With 1-2 ml/liter of water and for pest prevention usually used Syngenta with dose 0,2-0,4 ml/liter of water, cleaning weeds around the trees, and pruning of twigs that have dried up, twigs are burned and then buried. The nutrient nutrients analysis of N, P, and K fertilizers were carried out at Warmadewa University Laboratory and for soil analysis, while for nutritional analysis in Udayana University, Denpasar.

\section{Research Procedure}

Implementation was carried out in the field on durian plants of 20 plants taken randomly from plants used as research from the location used where the research location. Leaf picking starts from 2 months after harvest, then continued by the period of plant development, the period after the fruit harvest (before induction), the induction of flowers, flowers bloom and pentil fruit form. For leaf tissue analysis carried out in Udayana University Faculty of Agriculture Laboratory. For soil analysis, we take three points of observation location with $20 \mathrm{~cm}$ from the topsoil. It is then analyzed at Laboratory of Agricultural Faculty of Warmadewa University, Analysis of the N, P and K concentrations of the leaves, which was started by cleaning with tissue, and dried by the oven at $70^{\circ} \mathrm{C}$; the leaves were then blended and sieved with $0.5 \mathrm{~mm}$ sieve. The leaves were analyzed $\mathrm{N}$ nutrient concentrations. The total determination of Kjeldtec $\mathrm{N}$ using Kjeldtec (Appendix 1) (Tisdale et al., 1992). Chemical analysis was conducted based on the Laboratory of Faculty of Agriculture Udayana University, Denpasar Analysis of soil nutrient concentration, taken from the surrounding area around durian roots at 0-30 and $30-50 \mathrm{~cm}$ depth. The soil is drained and sieved with a $2 \mathrm{~mm}$ sieve to have the same relative size. Then the soil is analyzed soil chemical properties include: $\mathrm{pH}$, KTK element Nitrogen Determination of Nitrogen procedures and analysis the same as with leaf tissue analysis of durian.

From the observation to the three locations analyzed by analysis. If there is a real effect, followed by DMRT (Duncan News Multiple Range Test) tests at 5\% level. To calculate the relation between Nitrogen leaf content at each age (X), with relative production (\% Y) was analyzed by simple linear correlation using the following formula:

$$
\begin{gathered}
\mathrm{n} \sum X Y-\left(\sum X\right)\left(\sum Y\right) \\
r_{x y}=-\sqrt{\left.\left[n \sum X^{2}-\left(\sum X\right\}^{2}\right]\left[n \sum Y^{2}-\left(\sum Y^{2}\right\}\right]\right\}}
\end{gathered}
$$

Description: $r$-value shows the strength of the linear relationship. The correlation value is at the interval -1 $\leq \mathrm{r} \leq 1$ sign-and the + sign indicates the direction of the relationship. According to Sulaiman (2002) the size of the correlation is as follows: $0.70-1 \operatorname{good}(+$ (plus) or - (mines) indicates a high degree of association Correlation value $0.40-0.70$ (either + (plus) or - (mines) indicates a substantial relationship. Whereas 0,0 0,20 (either + (plus) or - (mines) means the correlation is negligible The nutrient concentrations Nitrogen leaves at age with high correlation value will be determined as the leaves of the sample for citrus plants, then on the calibration test activities, only those leaves are used. Variable Observed Field observations were leaf repayment; observed flower growth included: Nutrient content in the development period of durian crop shoots. Land retrieval at the three research sites and leaves then analyzed in the laboratory. For soil analysis in the laboratory of the Faculty of Agriculture, Warmadewa University, and Udayana University, while leaf tissue analysis in the laboratory of the Faculty of Agriculture, Udayana University Denpasar

\section{Results and Analysis}

\section{Changes in Leaf Nitrogen content with increasing plant life}

Between the periods of development of leaf shoots on durian plants have different concentrations between the four development of leaf reasoned. Concentration leaves at germination period of dormancy have the lowest nitrogen content, but there are similarities between the nitrogen content of shoot development, early, mature buds and shoots. When the growth of shoots on the plant durian nitrogen 
content will experience a decline, it is because fertilizer nitrogen is stable and is required as the fundamental building blocks of many important substances in the plant between; aim molecule chlorophyll amino acids, enzymes, coenzyme, vitamins, and hormones (Poerwanto, 2003). The same is true of mangosteen plants reported by Poovarodom et al. (2002) that there was a decrease in mangosteen nitrogen concentration during the growth period. So is the durian plant, which is observed by Poovarodon et al. (2000) where there is a tendency of nitrogen decrease in growth of shoot growth. The nitrogen concentrations observed by Poovarodom et al. (2002) may increase after the time of nitrogen fertilization in newly fertilized plants. Increased leaf age in mangosteen plants in the period of dormant buds, where the leaves have begun aging causes nitrogen decreased shrinking. It is caused the nitrogen fertilizer is a car which will cause translocation from the old leaf to the younger part of the organ so that the nitrogen concentration in the old leaves becomes a decrease in nitrogen. This is in contrast to the opinions of Yaacob and Tindalll (1995) as done on alfalfa plants by Rominger in Poerwanto (2002), Dow and Robert (1982) in potato plants. Both researchers stated that nitrogen concentrations were markedly marked by increasing plant life. In many developmental developments in soybean plants also showed a decrease in the concentration of nitrogen concentration. Where the older age of leaves eat lower concentrations of nitrogen content, but not significantly different with the nitrogen content between the development phase of dormant leaf buds with the gods despite an increase in the decrease in nitrogen, a dormant period of $1.12 \%$. The results of this study also supported by the opinion of Summer (1979) showed that for ten months observation of nitrogen concentration decreased between $28-72 \%$ during the period of the vegetative growth phase of mangosteen. Plants need proper care in their growth and development. One of the efforts to improve the productivity and quality of fruit is nutrient in plants. Inorganic fertilizers are widely available in the market to facilitate farmers in the fulfillment of nutrient elements. There are a variety of inorganic fertilizers according to their shape and content. Each inorganic fertilizer has an appropriate amount of nutrient content. One kind of inorganic fertilizer is NPK fertilizer containing nutrient nitrogen; plants much need phosphorus and potassium. NPK fertilizer has more nutrient content than single fertilizer. This fertilizer serves to accelerate the development of seeds. NPK fertilizers began to be given to plants at the beginning of vegetative growth (Novizan, 2002). Inorganic fertilization dose no specific benchmark. Due to the different types and soil fertility levels, the dosage of fertilization is different. Giving the right amount of fertilizer at the beginning of vegetative growth can affect the growth of the next durian. Farmers give inorganic fertilizer to newly planted durian seedlings

Leaf repopulation in fruit plants is divided into four periods of leaf repayment as in Siam citrus (Sulistiawati et al, 2016). The nitrogen content of the mangosteen weeds shows a significant difference in leaf nitrate nutrient concentrations from the three locations of perennial periods in plants between early budding developments, full buds, adult shoots and dormant buds. A very noticeable difference is the comparison between the early bud with the dormant bud. The concentration of each location of the observation is different, but between the location of Buleleng does not look that difference so meaning, At the time of the leaf is still young, the leaves do a large activity and require nutrition supply as well as more organic material in the early formation of leaf shoots on the plant durian.

Table 1

Leaf Nitrogen Nutrient Correlation Coefficient from Three Research Sites Sudaji, Munduk Bastala and Sinabun and Correlation Coefficient

\begin{tabular}{cccc}
\hline Budding development & \multicolumn{3}{c}{ nitrogen leaves concentration (\%) } \\
& Sudaji & Munduk bastala & Sinabun \\
\hline Early shoot period & $0,85^{* *}$ & $0,83^{* *}$ & $0,84^{* *}$ \\
\hline Full shoot period & $0,67^{*}$ & $0,66^{*}$ & $0,67^{*}$ \\
\hline Adult shoot period & 0,31 & 0,33 & 0,32 \\
\hline Dormant shoot period & 0,21 & 0,25 & 0,22 \\
\hline
\end{tabular}

Based on leaf nitrogen correlation analysis with shoot development during one period of growth after harvest on durian crops showed. There was a high association relationship between development of buddy with correlation coefficient $0,85^{* *}$ for early repayment, while $0,67^{*}$ for satisfaction, 0,31 . For adult

Suarta, M., Suaria, I., \& Sulistiawati, N. (2018). Build Recommendations Nitrogen Fertilization with the Development of the Period of Durian Crop Replanting. International Journal Of Life Sciences (IJLS), 2(1), 1-11. doi:10.29332/ijls.v2n1.73 
degradation and degradation for dormant is 0,21 for a research area of Sudaji area. For munduk bastala area at initial repayment 0,83 , full queue $0,66^{*}$, adult queue 0,33 and dormant equal to 0,25 . As for the location of research in Sinabun area initial repayment $0.84^{* *}$, full repayment $0.67^{*}$, adult queens 0.32 and dormant 0.22 (Table 1.). There is a very close relationship between leaf buds concentration and the period of budding development that is the initial short period, the full shoot period, the adult shoot period and the dormant shoot period. For durian coming from the Buleleng sponge in the initial splash, the highest correlation value is 0.85 , but it is sufficient meaning between leaf concentration with 0.52 correlation coefficient on dormant shoot period.

The relationship of soil chemical analysis showed that the concentration of nitrogen fertilizer concentration. The three research sites showed that the nitrogen content from low to very low levels of 0.0.13 to 0.07 (\%) was very low to low. According to the reference set by the research center land (2016) Warmadewa University Table 2, Soil nitrogen content decreases with increasing depth of soil; the same thing happened in three research sites. This opinion is corresponding with that revealed by Lestari (2003) that the more in the soil sampling, the more down the nitrogen concentration. It is caused by the high organic material that exists on the top soil layer in the three regions. According to Sulaiman (2002) the size of the correlation is as follows: $0.70-1$ good (+ (plus) or - (mines) indicates a high degree of association Correlation value 0.40-0.70 (either + (plus) or - (mines) indicates a substantial relationship. Whereas 0,0 0,20 (either + (plus) or - (mines) means the correlation is negligible. Nutrient, N, P, and K leaf concentration at age with high correlation value will be determined as the leaves of the sample for citrus plants; then on the calibration test activities, only those leaves are used.

Table 2

Relation of Nitrogen Nutrient Concentration with Development of Durian Cultivation in Three Locations of Sudaji, Munduk Bastala, and Sinabun

\begin{tabular}{lccc}
\hline The development of shoots & \multicolumn{3}{c}{ Correlation of leaf nitrogen concentration of shoot } \\
& Sudaji & Munduk bastala & Sinabun \\
\hline Early shoot period & $1,39 \mathrm{a}$ & $1,37 \mathrm{a}$ & $1,33 \mathrm{a}$ \\
\hline Full shoot period & $1,35 \mathrm{ab}$ & $1,27 \mathrm{~b}$ & $1,29 \mathrm{~b}$ \\
\hline Adult shoot period & $1,31 \mathrm{abc}$ & $1,23 \mathrm{c}$ & $1,12 \mathrm{~b}$ \\
\hline Dormant shoot period & $1,29 \mathrm{ab}$ & $1,20 \mathrm{c}$ & $1,09 \mathrm{~b}$ \\
\hline
\end{tabular}

Research location in Buleleng area which has the highest acidity at depth $0-30 \mathrm{~cm}$, it is necessary to take calcification action. The $\mathrm{pH}$ range at the three sites ranges from research, and the nitrogen content will decrease with deeper soil taking to a depth of $50 \mathrm{~cm}$. For soil sampling in the framework of soil analysis to perform fertilizer efficiency at planting should be taken at a depth of $30 \mathrm{~cm}$. Of the three sites used as research sites for the $\mathrm{pH}$ range belonging to the three regions of durian production centers were 4.87 to 3.21. It means that the three research areas are very acidic to acid, so it needs to be given calcification action. The more so in the soil sampling, from the third location research the degree of acidity is very acid to acid. The low degree of acidity in the three locations of bias due to the washing of soil at the study site due to the presence of high rainfall during the rainy season. If linked from the results of soil analysis performed it contains nutrient content such as $\mathrm{Mg}$, $\mathrm{Ca}$, and $\mathrm{K}$ are very low in the three research sites. Given the differences in nitrogen content, KTK, and soil pH at the three research sites, it also causes the effect of nutrient uptake on plants. The result of soil analysis and leaf analysis on the development of the peak period at the location of Buleleng area of soil nitrogen content is highest. Whereas in the bud shoot period the crew and the full shoot of the highest nitrogen content this is due to the high content of organic material in the upper layer and decreased with increasing the depth of the soil. 
Table 3

Nitrogen, KTK, and acidity (pH) concentrations observed in three research sites of durian plant

\begin{tabular}{|lccccc|}
\hline Location & depth of soil & & \multicolumn{3}{c|}{ Soil analysis } \\
& & $\mathrm{N}$ & $\mathrm{KTK}$ & $\mathrm{pH}$ \\
& $(\mathrm{cm})$ & $(\%)$ & $\mathrm{me} / 100 \mathrm{~g}$ & $\mathrm{H} 20$ & $\mathrm{KCL}$ \\
\hline Buleleng & $0-30$ & 0,17 & 17,97 & 4,35 & 3,82 \\
& $30-50$ & 0,15 & 14,76 & 4,87 & 3,75 \\
\hline Bangli & $0-30$ & 0,14 & 19,13 & 4,71 & 3,54 \\
& $30-50$ & 0,12 & 15,27 & 4,36 & 3,47 \\
\hline Gianyar & $0-30$ & 0,15 & 15,11 & 4,53 & 3,21 \\
& $30-50$ & 0,10 & 13,09 & 4,12 & 3,09 \\
\hline
\end{tabular}

The closeness of the relationship between the nutrient content of nitrogen and leaf tissue analysis with nutrient content of nitrogen in the soil in the development of the period of prepayment in durian plants seen have a very associated association. The correlation coefficient of leaf concentration in early reproduction with the concentration of nitrogen nutrients in soil was $r=0.82$, while the soil correlation coefficient was $r=0.80$. The Nutrient leaf concentration positively correlated with the development of the reproductive period on the durian crop. Seen from the development of physiology of the younger reproduction of leaf buds the higher the nitrogen content, so also from the analysis of the soil in the soil acquisition of the nutritional value contained less and acidity of the soil increasingly acid, so it needs liming. This situation in line with the opinion Poerwanto (2002) which in general on the growth of fruit plants are divided into three, namely vegetative growth starting from the end of harvest until the initiation of flowering, initiation of flowers, and filling of fruit. At the time of vegetative growth, it takes all the nutrients provided in a balanced state including the provision of organic materials to improve the physical, chemical, and biological properties of the soil, and calcium for the pH stabilizer. Nitrogen fertilizer (N) is done every year or at the beginning and end of the rainy season so that the availability of nutrients in the soil is maintained to meet the needs of Hanif at al. (2013).

\section{Conclusion}

1. Nitrogen fertilizer concentration existing in leaf buds will decrease by the development of shoots of durian plants, where the older leafage in the plant the nitrogen content is decreasing.

2. The nitrogen content present in the leaf tissue is positively correlated with the nitrogen content present in the soil at the three study sites.

3. The nitrogen concentration in the leaf is positively correlated with the development of the reproductive period on the durian plant.

\section{Acknowledgements}

Praise gratitude authors the presence of God all night, so that this simple writing can be solved can finish this paper thanks to some help from:

1. The Rector Warmadewa University for his permission to conduct research

2. The Dean Agriculture Faculty Warmadewa University, the volunteered to provide some facilities so that the research could run

3. Thanks to the editor-in-chief of IJLS who has helped in the acceptance of my writing that is still far from perfect all the parties that I can not mention one by, at the end of the word I say many thanks to all parties.

Suarta, M., Suaria, I., \& Sulistiawati, N. (2018). Build Recommendations Nitrogen Fertilization with the Development of the Period of Durian Crop Replanting. International Journal Of Life Sciences (IJLS), 


\section{References}

1. YI, S., WANG, X., LI, N., WEI, J., \& DAI, C. (2008). Research Progress in Activation Treatment Technology of Activated Carbon [J]. Materials Review, 3, 020.

View in (Google Scholar)

2. Statistik, B. P. (2012). Produksi Buah-Buahan Menurut Provinsi. Badan Pusat Statistik, Jakarta. View in (Google Scholar)

3. Dow, A. I., \& Roberts, S. (1982). Proposal: Critical Nutrient Ranges for Crop Diagnosis 1. Agronomy Journal, 74(2), 401-403.

View in (Google Scholar)

4. Rohman, H. F., Hariyono, D., \& Ashari, S. (2013). Pemupukan NPK pada tanaman durian (Durio zibethinus Murr.) lokal umur 3 tahun. Jurnal Produksi Tanaman, 1(5).

View in (Google Scholar)

5. Leiwakabessy, F. M., \& Sutandi, A. (2004). Pupuk dan pemupukan. Fakultas Pertanian. IPB Bogor, 208. View in (Google Scholar)

6. Liferdi, L., Poerwanto, R., Susila, A. D., Idris, K., \& Mangku, I. W. (2008). Korelasi kadar hara fosfor daun dengan produksi tanaman manggis. Jurnal Hortikultura, 18(3).

View in (Google Scholar)

7. Ashari, S., Hariyono, D., \& Triliestyana, Y. (2016). Response Initial Vegetative Growth of Local Durian (Durio zibethinus Murr.) with The Addition of Organic Fertilizers. PLANTROPICA: Journal of Agricultural Science, 1(1).

View in (Google Scholar)

8. Poerwanto, R., Efendi, D., \& Harjadi, S. S. A. (1997). Pengaturan pembungaan mangga Gadung 21 di luar musim dengan paklobutrazol dan zat pemecah dormansi.

View in (Google Scholar)

9. Poerwanto, R. (2003). Bahan ajar budidaya buah-buahan. Modul VII. Pengelolaan tanah dan pemupukan kebun buah-buahan. Program studi hortikultura Fakultas Pertanian, Institut Pertanian Bogor.

View in (Google Scholar)

10. Poovarodo, S, N Rainteung, S Mairaing, J Prasittikhet and P Ketsayom. (2000). Seasonal variations in nutrient concentartions of durisn (Durio zibetinus Murr) leaves, Acta Horticulturae 564:235-242

View in (Google Scholar)

11. Poovarodo, S. P Kanyawonga, Plentrat, and N Boonplang. (2002). Leaf age and position on mineral composition of mangosteen leaves. Presntation paper Symposium No.16-17 th WCSS, 14-21 Agust 2002. Thailand.

View in (Google Scholar)

12. Arum, 1. S. Respon pertumbuhan dan ekspresi gen ascorbate peroxidase pada umur bibit melinjo yang berbeda setelah cekaman kekeringan.

View in (Google Scholar) 
13. Reddy, Y. N., \& Bhagwan, A. Induction Of Flowering In Fruit Crops-Physiological And Plant Architectural Implications. Souvenir, 24.

View in (Google Scholar)

14. Setiawan, E. (2005). Produktivitas dan kualitas buah manggis pada berbagai posisi cabang dalam tajuk. View in (Google Scholar)

15. Sulaiman, W. (2002). Jalan Pintas Menguasai SPSS 10. Yogyakarta: Penerbit Andi. View in (Google Scholar)

16. Sulistiawati Anom N.P and Kartini. L. (1916). Identiifikasi fase-fase perkembangan dan perubahan pucuk berbunga dan tidak berbunga pada tanaman jeruk Siam. Hibah fundamental yang dibiayai RISTEK DIKTI tahun anggaran 2016.

View in (Google Scholar)

17. Letzsch, W. S., \& Sumner, M. E. (1984). Effect of population size and yield level in selection of diagnosis and recommendation integrated system (DRIS) norms. Communications in Soil Science and Plant Analysis, 15(9), 997-1006.

View in (Google Scholar)

18. Meyer, J. H. (1981, June). An evaluation of DRIS based on leaf analysis for sugarcane in South Africa. In Proc. S. Afr. Sugar. Tech. Assoc (Vol. 55, pp. 1-8).

View in (Google Scholar)

19. Yaacob, O., \& Tindall, H. D. (1995). Mangosteen Cultivation. FAO Plant Protection Paper 129. Food and Agriculture Organization of the United Nations, Rome, 100.

View in (Google Scholar)

20. Jain, P., Jain, A., Singhai, R., \& Jain, S. (2017). Effect of Biodegradation and Non Degradable Substances in Environment. International Journal of Life Sciences (IJLS), 1(1), 58-64.

View in (Google Scholar)

21. Ogu, G. I., \& Orjiakor, P. I. (2017). Microbiological and Nutritional Qualities of Fermented Melon Seed Shells. International Journal of Life Sciences (IJLS), 1(2), 1-9.

View in (Google Scholar)

22. Singh, D. (2017). Leaf Phenology of Cassia Sieberiana L. in KSUSTA Campus of Kebbi State, Nigeria. International Journal of Life Sciences (IJLS), 1(1), 1-8.

View in (Google Scholar)

23. Suryani, S. A. M. P., \& Arya, I. W. (2017). Improving the Quality of Tilapia (Oreochromis niloticus) With consumption measures Leaf Extract Neem (Azadirachta indica A. Juss) as Antiparasitic. International Journal of Life Sciences (IJLS), 1(3), 28-37.

View in (Google Scholar)

24. Saxena, A. (2017). The Impact of Nutrition on the Overall Quality of Life Adolescent Girls are Living Across the City of Kota. International Journal of Life Sciences (IJLS), 1(1), 40-48.

View in (Google Scholar)

25. Sulistiawati, N. P. A., Kartini, L., \& Yuliartini, M. S. (2017). Identification of Development Phases and Changes Shoots Flowering Orange Siam Plants. International Journal of Life Sciences (IJLS), 1(2), 28-38. View in (Google Scholar)

Suarta, M., Suaria, I., \& Sulistiawati, N. (2018). Build Recommendations Nitrogen Fertilization with the Development of the Period of Durian Crop Replanting. International Journal Of Life Sciences (IJLS), 2(1), 1-11. doi:10.29332/ijls.v2n1.73 
26. Ajwa, H. A., Dell, C. J., \& Rice, C. W. (1999). Changes in enzyme activities and microbial biomass of tallgrass prairie soil as related to burning and nitrogen fertilization. Soil Biology and Biochemistry, 31(5), 769-777.

View in (Google Scholar)

27. Lee, K. H., \& Jose, S. (2003). Soil respiration, fine root production, and microbial biomass in cottonwood and loblolly pine plantations along a nitrogen fertilization gradient. Forest Ecology and Management, 185(3), 263-273.

View in (Google Scholar)

28. Ercoli, L., Mariotti, M., Masoni, A., \& Bonari, E. (1999). Effect of irrigation and nitrogen fertilization on biomass yield and efficiency of energy use in crop production of Miscanthus. Field Crops Research, 63(1), 311.

View in (Google Scholar)

29. Wallenstein, M. D., McNulty, S., Fernandez, I. J., Boggs, J., \& Schlesinger, W. H. (2006). Nitrogen fertilization decreases forest soil fungal and bacterial biomass in three long-term experiments. Forest Ecology and Management, 222(1-3), 459-468.

View in (Google Scholar) 


\section{Biography of Authors}

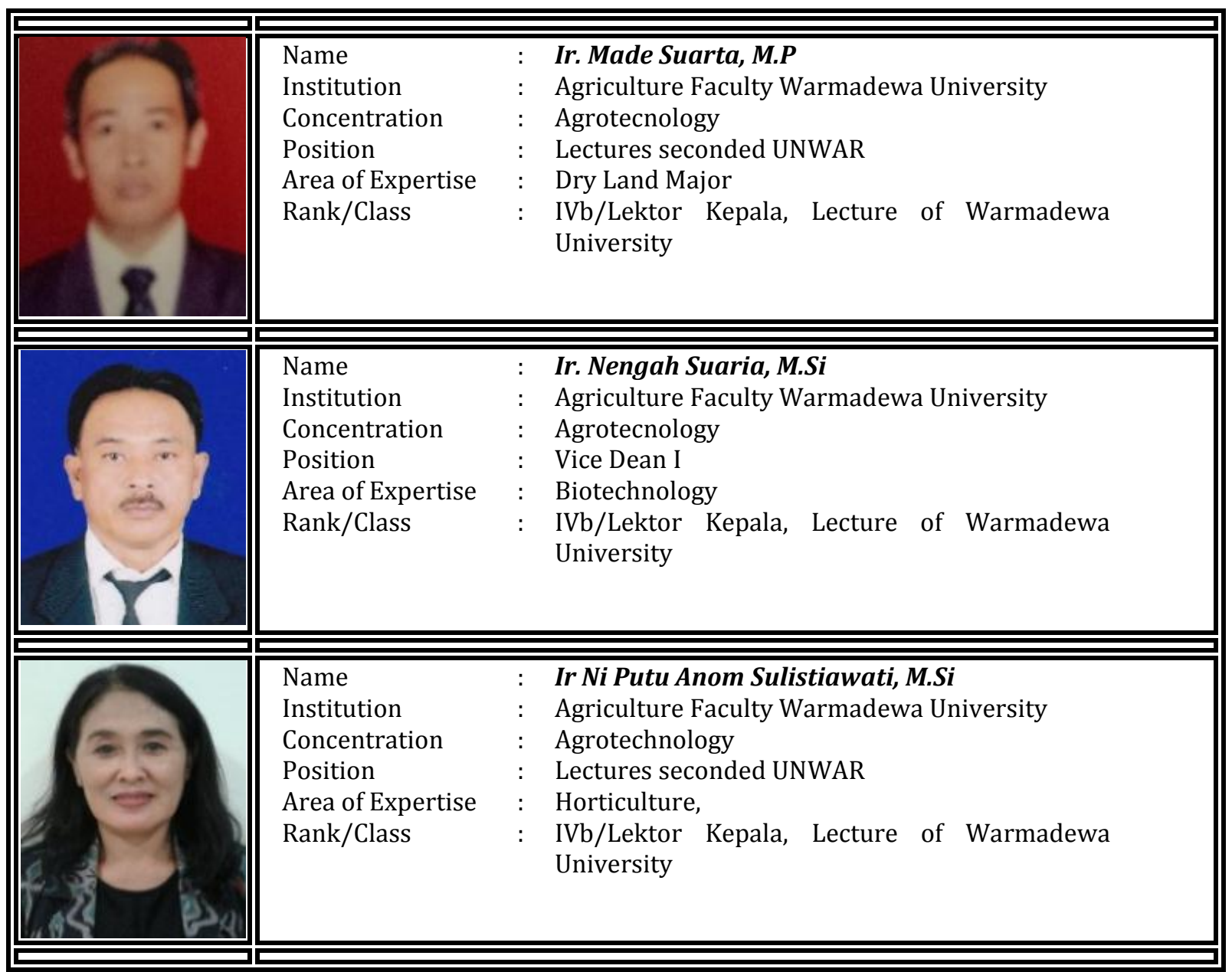

Suarta, M., Suaria, I., \& Sulistiawati, N. (2018). Build Recommendations Nitrogen Fertilization with the Development of the Period of Durian Crop Replanting. International Journal Of Life Sciences (IJLS), 2(1), 1-11. doi:10.29332/ijls.v2n1.73 